\title{
Flying Flags of Fear: The Role of Fear in the Process of Political Transition*
}

\author{
BRANDON HAMBER
}

\begin{abstract}
An Israeli flag is held taut by the wind, its blue and white colours brighter as the sun breaks through a gap in the clouds. But the sky against which this flag flies is not the expanse that blazes over the Golan Heights or Galilee. This is Belfast. And the community that hoisted it up was not an Israeli community living in Northern Ireland, either. Instead, it's an emblem among all the other cultural signs that crowd this small space. This flag is in The Village, a loyalist enclave in north Belfast where Union Jacks are in plentiful supply, murals of William of Orange decorate gable walls, and the kerb stones are painted red, white and blue. Nothing seems further removed from Protestant Unionism and fiercely held Northern Irish links with Britain than the symbol of Israeli culture, but this isn't an isolated display. In certain areas across Belfast, the most potent declaration of Israeli nationalism is flying high, but so out of its original context that its significance has taken on a completely different meaning.
\end{abstract}

C. Dwyer Hogg (2002)

This article outlines some unfolding ideas about fear, risk, and social change and their application to the process of political transition. It is about diverse forms of symbolism - as the quotation above indicates - as well as the confluence and divergence of micro (individual) and macro (political) approaches to dealing with and thinking about the legacy of political violence. The article analyzes the role of fear in the political transition process, a subject seldom treated in the academic literature. To this end, it presents a range of ideas and theoretical contemplations that will hopefully open further academic space for explorations of the concept of fear within political transition processes and debates on transitional justice.

The article draws on my experience of the peace processes in Northern Ireland and South Africa. It begins by offering some thoughts on the strange phenomenon mentioned above - the flying of Israeli flags by Protestant Unionists/loyalists in Belfast. After briefly outlining how psychological and sociological literature approach the concept of fear (and risk), it argues that fear and the use to which it is put are unrecognized variables operating within the popular discourses surrounding

*First published in Bulletin of the Royal Institute for Inter-Faith Studies 6, no. 1 (Spring/Summer 2004), pp.113131. Reprinted with permission. 
political negotiations and processes such as truth commissions. It next examines the way in which the concept of fear is politicized and depoliticized-much like the suffering of victims of political violence. The article concludes by trying to apply some of the ideas that it presents to the South Africa and Northern Ireland contexts and, particularly, to approaches to political risk taking.

\section{FLYING FLAGS OF FEAR}

As tension mounts during the buildup to the Orange marching season, which occurs each summer in Northern Ireland, the streets of many of its cities and towns are festooned with flags. The proliferation of Union Jacks, Irish Tricolors, Ulster flags, and paramilitary banners that adorn the streets symbolize loyalty and serve as sectarian markers of territory. In July 2002, however, something unusual happened: Republicans started hoisting the Palestinian flag alongside their Irish Tricolors, whereas in neighboring loyalist areas the Israeli flag suddenly appeared and fluttered alongside the United Kingdom's Union Jack and the banners of various paramilitary organizations. In some places, the trend seemed short-lived, but Israeli flags, in particular, continued to find their way onto lampposts in some loyalist estates during the following summer.

To add to this strange turn of events, in early April 2002, as American tanks entered Baghdad and British troops apparently took control of Basra, US President George W. Bush flew into Northern Ireland for a war summit with British Prime Minister Tony Blair. The principal issues on the agenda were the fate of postwar Iraq and informal talks about the state of the Northern Ireland peace process, including President Bush's endorsement of it. The two leaders met at Hillsborough Castle where, according to a British spokesman, they tried to recreate a "Camp David" atmosphere (O'Clery and Moriarity 2003). It is difficult not to approach the reasons for this meeting cynically: As one commentator put it, the meeting was "a piece of theatre: a nice gesture to Tony Blair, a peace-making photo-opportunity to counterpoint the images of war on Fox News" (O'Toole 2003: 18). Needless to say, few were duped by this naked propaganda, and in terms of the Northern Ireland peace process, the meeting had no effect.

What is the significance of these stories? First, they highlight how the issue of security has become globalized, albeit in a seemingly confused, overlapping, and multilayered way. Second, and for the purposes of this article, they say something about the concept of fear and its role in political transitions.

On one level, the flying of the Palestinian flag may simply be a gesture of solidarity with a cause that republicans support and have always supported. It may also be, although no one has stated this publicly, an attempt to compare the two situations. I say this despite the fact that it seems questionable that republicans can credibly claim they currently share a level of hardship similar to the one experienced by Palestinians or that loyalists can argue that they feel a level of threat similar to

the one endured by Israelis. On a more frivolous level, the flying of the two flags may simply be symbolic of division, a way of trying to outdo one's adversary. As 
David Ervine, leader of the Progressive Unionist Party, the political wing of the Ulster Volunteer Force, and a minor player in the Good Friday Agreement talks, commented: "It becomes a badge that's meant to upset the others.... All I want to say is that if one side put a Tamil flag up, the other would put up a Sri Lankan one" (Dwyer Hogg 2002: 6).

But the flying of the flags may also symbolize a range of conscious or, perhaps, subliminal fears. Speculatively, for some republicans, the Palestinian flag symbolizes the place from which they believe they have come (oppression) and to which they do not want to return (conflict). This is why their constituents are urged to continue to support the Agreement of 1998. Perhaps, for some loyalists, the Israeli flag represents the opposite, that is, a fear of what might happen if they continue to support the Agreement-namely, that they may become hemmed in and surrounded by a hostile "other."

\section{POLITICAL TRANSITION AND FEAR}

The concept of fear is central-even if rather silently so- to many of the general themes of modern social and political thought (Tudor 2003). Despite its importance to growing sociological thought on risk, which presupposes different senses of fearlessness and fearfulness in a 'risk society,' it is generally untheorized (Tudor 2003). In psychology, despite the ever-increasing literature on fear (and phobias), the subject is generally dealt with through the prism of the clinical and biological and is largely acontextually. It is approached in criminology and social policy studies mainly in terms of the fear of crime and questions concerning security and uncertainty, but it is hardly a central tenet.

Fear as a concept, and its relationship to political and social contexts has received little academic attention. The role of fear-and, to a degree of risk-is seldom theorized about or examined in relation to the concept of political transition. ${ }^{1}$ For example, in the case of the "transitions" in postsocialist Europe, it has been argued that the emotional dynamics involved in them has been virtually ignored by scholars who have favored looking at the economic, political, legal, and social dimensions of these phenomena (Svasek 2002).

This is not to say that the concept is not dealt with in some contexts. Fear is often discussed in terms of how it maintains and creates divisions in conflicted political environments. For example, in what Crawford Young calls a primordial understanding of ethnicity, according to which groups divide into "we" and "they" categories due to the human need for belonging, fear is a singularly powerful emotional field that helps the negative stereotype to mutate into apprehensions of hostile behavior on the part of the ethnic "other" (Young 2003). This supports and can escalate conflict.

In Belfast in Northern Ireland, it has also been found that mental maps identifying "safe" and "unsafe" areas for different communities in troubled areas have persisted throughout the conflict (Burton cited in Shirlow et al. 2002). The extreme result of this real and perceived threat has been the construction of "peace walls." In 
themselves, these peace walls have become "the malevolent face of the people who live on the other side" (Feldman 1991). The gradual acceptance of this ethnosectarian apportionment nurtures the belief that the "other" community is committed to harm (Shirlow et al. 2002). In essence, the fear of the other is a reason for and perpetuates the divisions that linger in the peace process today.

The political appropriation of fear in conflict situations is also an issue that receives mention, especially its use by politicians (not to mention the public, professionals, and institutions). It is fairly commonplace today to hear the analysis that US foreign policy on Iraq and the "fight against terrorism," for example, are designed to "keep people's attention away from what you're doing (on domestic matters)" (King 2002; emphasis is mine). The fear of foreigners and immigrants manifested as xenophobia has also become a populist fear-based platform in many countries. The issue is routinely used to win votes on a bedrock of perceived (and generally exaggerated) fears of being swamped by outsiders supposedly eager to take the jobs of locals and dilute local culture.

In South Africa, crime has additionally been used as a political issue grounded in the politics of fear. All parties contesting the second democratic election in June 1999 , for instance, used the high crime rate as a major political rallying point. Examples include political rhetoric such as "Hang Murderers and Rapists" (New National Party slogan), "Fight Back" (Democratic Party slogan), and the Democratic Party's haunting radio advertisements that featured an endless litany of acontextual statistics about the chances of being victimized. Most of these campaigns exploited the fear of the population that crime is spiraling out of control (for a more detailed discussion see Hamber 2000). This perception fed the already rampant fear that continues to permeate much of the current South African mindset. Crime rates are genuinely high, but the general population's fear of victimization is, on the whole, out of proportion to the real threat (Camerer et al. 1998). The fear of crime is used as code for political unease (Cohen 1996) and, sometimes, for racism toward African-dominated governance (Saul 2002) in that some white South Africans use crime rates as a way of arguing (with racist overtones) that the current government is incompetent or that its members are themselves somehow linked with crime.

Fear can also be used in other, ostensibly, more "positive" ways. Underpinning all political transition processes is a range of social and individual fears both real and imagined. These are built on the experience of the past (as well as collective transgenerational memories and myths of the past), embedded in the present and mediated through the local and global context, and constantly being held up against the uncertainty of what might happen in the future. Arguably, peace agreements and those mechanisms born through them, such as truth commissions, are profoundly shaped by this process and by the discourses of fear.

The discourses of risk and fear are central to most peace processes; indeed, the necessity of taking risks, setting aside fears, and building trust are frequently heard in South Africa and Northern Ireland, and elsewhere. But it is the discourses of fear (justified as having a positive outcome) underpinning peace processes that are of more direct interest to us here. That is, the threat that if peace is not made, 
further conflict will ensue. The South African Truth and Reconciliation Commission (TRC) was, on one level, justified in using a (reversed) form of the politics of fear. A popular rationale for the TRC was that if a reconciliation mechanism was not put in place and amnesty granted, the country would disintegrate and sink back into conflict. Archbishop Tutu, chairperson of the TRC, is famously quoted as saying the following:

If the security forces had thought that they were going to be up for the high jump we would not have had a negotiated settlement, that is the price that had to be paid, and yes, the victims and survivors are probably asked a second time and to be willing - if this high price had not been paid this country would have gone up in flames (cited in Ignatieff 1997).

At the same time, it was constantly reiterated (mainly to conservative whites) that they had nothing to fear from the process-there would be no "witch hunts." Although conflict may well have continued had various compromises not been made, it is interesting to consider how the no alternative to amnesty discourse has become entrenched within discussions about the formation of the TRC. In fact, most negotiated political transitions are spoken about in this way, for "they represent the moment of interaction at which all major stakeholders realize they are at risk-there is no returning to the previous system and power needs to be carefully used in order to secure the future" (Anstey 1998: 52).

In Tomorrow Is Another Country: The Inside Story of South Africa's Negotiated Revolution, Allister Sparks eloquently expresses the essence of the "no alternative" understanding of the South African peace process:

For this was always a crisis-driven process. From the moment De Klerk made his fateful announcement on February 2, 1990, there could be no turning back. There was no way he could ban the ANC or any other black movement again, return Mandela to prison, or revert to apartheid. With his political opponents in the same boat, he had embarked on a one-way voyage, and they could either arrive at a new shore together or sink together. There were no other options. So as each new crisis reminded these squabbling voyagers afresh of their mutual dependency, they leaned on their oars with renewed effort and pulled for the shore (Sparks 1997: 178).

Of course, there is some truth in this and in statements above about the real risks of ongoing conflict. There is also the reality of the fear created by years of repression and the heartfelt desire, found in most societies coming out of conflict, to move away from past tensions and circumvent the genuine threat of further violence. Many would argue that the "compromises" and assurances made in South Africa, particularly concerning amnesty, were merely pragmatic (Tutu 1999; Boraine 2000). But the point here is that it was pragmatism riding on the back of the fear of what might happen.

The need to avert, at all costs, possible future violence and the fear that it might return and spiral out of control was a message constantly conveyed to the general population in South Africa by the principal negotiators. However, this fact 
draws our attention to a curious state of affairs. The polemical statements heard at times of transition (such as "without compromise there is no peace" or "without amnesty there will be more conflict") imply that conflict exists separately from the political context - that it stands completely outside of the control of the politicians who are making these same statements about the potential for further conflict. This may be true, in some cases, but the implied disjuncture is interesting to consider.

Until now, the literature on transitional justice has paid no attention to the role of real and imagined fear in shaping transitional justice mechanisms or to formulating a meta-analysis of the way risk and fear are used during political transitions. In fact, most academic works in the field treat fear and anxiety about further conflict as a real and existing phenomenon that can only be addressed through new political arrangements. Seldom are politics and political forces (many of which are represented at the negotiating table) named or recognized as, in many cases, the primary source and potential panacea for the fear.

\section{FEAR, POLITICS, AND THE CONTEMPORARY}

In his conceptual history of fear, Corey Robin argues that fear is largely, in the modern world, constructed as standing outside of the realm of politics (Robin, 2000). Drawing on work by Judith Shklar, Robin concurs that one of the cardinal assumptions of contemporary liberalism is that fear arises in the absence of moral principles, laws, and institutions (Shklar 1989; cited in Robin 2000). Politics may well incite fear or fear may even intrude on politics, but the basic characteristics of fear are generally not thought to be political creations (Robin 2000). In short, he contends that there has been a shift from politics to psychology and culture in our conception of fear and that this shift makes it difficult to understand the sources of fear. He writes the following:

Instead of analyzing the ways in which the state and elites throughout civil society actively foster and maintain fear, they look to the realms of culture and social psychology for the clues to our current predicament.

This has intersected with (and is also part of) the growth of expressive psychologically minded individualism (Summerfield 2001), particularly within the Western world, which is integrally linked, in turn, to the firm embrace of the concept of "victim" rather than its rejection (Novick 2001). Summerfield (2001) startles us by observing that a recent editorial in the American Journal of Psychiatry commented that it was rare to find a psychiatric diagnosis that anyone liked to have, but that posttraumatic stress disorder (PTSD) seemed to be one. Controversially, Ian Buruma (1999) argues that an "Olympics of suffering" has developed across the world as different societies try to compete with the Holocaust. Others, too, have made similar observations: Note Novick's (2001) use of the phrase "Olympics of genocides" and Cohen's (1996) reference to a "moral Olympic games between competitors claiming superior status for their particular psychic suffering." 
It appears as if the cultural icon of the strong silent hero has been replaced by one exalting the vulnerable anti-hero (Novick 2001). Sensitivity has replaced stoicism, and voicing pain and outrage is said to be "empowering" as well as therapeutic, (Novick 2001). Indeed, holding pain in is considered to be dangerous. We are encouraged to express our fears while being on our guard against all sorts of risks-from serial killers to the rampant spread of new diseases throughout our societies.

Fear, like suffering, has come to be increasingly linked with psychopathology. The word "trauma" has become a catch-all that moves with ease between the realms of the clinical (typified by the common diagnosis of $\mathrm{PTSD}^{2}$ ) and the popular media (think of the everyday "trauma" of living so fashionably on television talk shows). The language of suffering has permeated many aspects of public (largely Western) life. Cohen (1996) argues that this so-called culture of victimization has emerged from identity politics, with groups defining themselves largely in terms of their claim to special identity and suffering.

\section{POLITICS IS PERSON}

Although the rights of victims of political violence remain underdeveloped, whether morally, ethically, legally, or in practice (Hamber 2002), in the transitional justice debate, the "victim" of political conflict has become fairly central to political negotiation processes. This can be positive, and it is certainly important in terms of the potential attainment of victims' rights. But the suffering of victims can also serve as a bargaining chip, a means to entitlement and a moral issue used to score political points against one's adversaries. Victims become political capital for politicians who seek to use and manipulate their suffering, often for their own political ends. Reflecting on postsocialist Europe, for example, Svasek notes the following:

It is common practice for nationalist politicians to select and incorporate particular historical narratives and emotional memories into their political discourse as a rhetorical device to evoke and strengthen nationalist sentiments (Svasek 2002: 14).

In Northern Ireland, one often hears people talking about a "hierarchy of victims." Research (Deloitte and Touche 2001; Morrissey and Smyth 2002) has found a continued hijacking of the so-called victim issue, both in terms of individuals and in terms of defining one "community" or the other as the "real" victim. At the collective level, politicians generally broaden the criteria used to identify a victim when it comes to their own political grouping and narrow them for their opposition. In some cases, whole communities are referred to as victims.

The result of this at the individual level is that people who have suffered terrible losses are often left feeling abused and as little more than one small part of a wider political agenda. Indeed, there is evidence that victims are being targeted by all parties seeking to make various claims of protecting and assisting them as 
part of their political platforms in Northern Ireland (Cap Gemini Ernst and Young 2001).

Ultimately, the individual is simply defined as the victim or, more typically, is referred to by the media solely in terms of his or her murdered loved one (as in "the wife of..."). Such individuals are also very quickly labeled as belonging to one or another political tradition (Protestant or Catholic), even though this may not reflect their own personal understanding of their identity or of their victimization. Ironically, although their suffering finds expression in the political arena (through the words of politicians or, in some countries, a public truth-recovery process), the content and context of their suffering-their "real" personal experience of it and the political framework that lies at its root-always run the risk of being sidelined, misrepresented, and conflated with multiple agendas.

The participation of victims in truth commissions may also be used in this way. Victims participating in public truth-recovery processes are engaging in a profoundly political process, but the social and personal meaning of why they are there (their suffering) is difficult to convey. ${ }^{3}$ Generally, it is the wider social significance of the testimony (and the fact that they are the victims of specific types of human rights violations at the hands of specific individuals) that receives prominence. This leaves an inevitable disjuncture between the personal and the collective.

Michael Humphrey argues that the centerpiece of most recent truth commissions is individual suffering: The source of truth is largely the stories of the victims' suffering. Yet, the power of their words is empathetic and not legal, and the sharing of truth has a moral implication in that it is supposed to engender acknowledgement and collective responsibility (Humphrey 2002). In addition, the testimony of the victim is used as an example of the negative consequences of the political ideologies of the past. The victim symbolizes the dangers of maintaining or returning to conflict, perhaps even tapping into common fears that, without compromise, we might all become damaged victims parading our wounds for the world to see.

The social use of the narrative of the victim (in this case, to advance reconciliation and peace) may well become more important than his or her individualized suffering. Plainly stated, the very nature of the process causes the victims themselves and their participation in it to signify or embody a social purpose that stands (at least to some degree) outside of their own experience.

Of course, this is not a simple linear process, and it may have some benefit for the individual. Many victims have a strong desire to testify, and they often identify speaking out as valuable and desirable. Hence, from a psychological perspective, truth commissions can be beneficial to those participating in them, although the process is hardly sufficient and the impact is not necessarily positive (Hamber 1998, 2001). That being said, the social purpose of participation-and the contingent benefit of testimony (and, perhaps, getting the truth) —will seldom overlap with the social or collective meaning of victims' participation at the political level. It can even result in their individual needs being socially and politically marginalized. 
Thus, we can see, through the prism of the truth commission in this case, that the personal has, in contemporary society, become linked with the political, albeit in a fairly confusing way. Not only is the person political, but the political, is the person ( $c f$. Cohen 1996). The "self" is understood as a personal and political entity (Svašek 2002). As a result, not only are political issues focused on one entity ("the people," "the community," or "the nation"), generally resulting in rigid social, psychological, and cultural boundaries ("the ethic group"), but solutions to the political and social problems of that entity can also end up being sought through the individual.

\section{THE FEAR OF POLITICS}

We need to be wary of collapsing the individual into the collective or political process or of speaking about political processes and societies as if they have psyches and exist in ways similar to individuals (Hamber and Wilson 2002). Political situations should not be embodied with a sense of collective emotionality, identity, and psychology, for in so doing we obscure and dilute their political essence. To expand on, and to return to, the issue of Israeli and Palestinian flags in Northern Ireland, I would hypothesize that if you interviewed a number of people, especially in largely Protestant areas, and asked about the symbolism of flying an Israeli flag, the discussion would come back, at some point, to the need to deal with a perceived threat from the "other." This would quickly lead to the subject of Protestant identity, specifically, the complaint that "Protestants feel that their identity is under threat" due to the political changes now occurring in Northern Ireland. Members of the community presently believe - or so it is commonly articulated-that theirs is a community of "new" victims, "victims," that is, of the compromises of the peace process. They put this state of affairs in sharp distinction to "Catholic identity," which is viewed as positive, on the rise, confident, and articulate-Catholics are moving, in the minds of many, from victims to survivors.

In Northern Ireland, there is a strong perception that as things have begun to change, many people, specifically those living in largely loyalist working-class Protestant areas, have been left in a state of anomie as the familiar crumbles, social bonds break down, and old stable identities, power relations, and norms are challenged. ${ }^{4}$ This has led to the start of a debate about how to deal with this alienation, uncertainty, and instability, which is not completely exclusive to the Protestant working class.

At the core of the debate lies one question: Should the funding agencies that support the peace process fund "single-identity work" or "cross-community work"? The first of these options, single-identity work, involves work in communities perceived as being composed of one ethnic group, and it is intended to build up the confidence of individuals and strengthen their sense of identity so that they can engage, at some future date, with other groups on an equal footing to further diversity and build relationships. The second option, cross-community work, is work aimed at bringing members of different groups together to promote tolerance, 
sharing, diversity, and relationship building. Some have asked whether supporting single-identity work will have the desired outcome of ultimately ensuring mutual engagement and cultural diversity or whether its support will merely make divisions worse. Recently, the Community Relations Council (CRC) $)^{5}$ of Northern Ireland wrote the following:

\footnotetext{
Often the only visible safe space is identified as 'single identity', meaning a context in which the community background of all participants can be presumed. CRC believes that safe but exclusive space can be an essential part of a process which ultimately ends in engagement and meeting. However, single-identity projects can too often be excuses to avoid reality, building up a false, aggressive or bombastic confidence which does little to prepare people for real confidence in real relationships across cultural lines. Projects which are described as cross community projects in the 'long term' become in effect projects in which any real relationship is put on the long finger (Community Relations Council 2003).
}

This is interesting because it brings our discussion back to the question of the relationship between politics, emotion, and fear. On one level, it may make perfect sense to wish to avoid forming relationships with the "other" after conflict or to be anxious about the power implicit in the relationship (if one party is more confident than the other or has a stronger sense of self). However, on another level, the "single-identity" and "cross-community" debate highlights the degree to which the context of politics (for instance, the nature of the state, institutional power, and democracy) is becoming increasingly mixed with the politics and language of the individual. Stanley Cohen (1996) challenges this development, asking why "selfunderstanding," "identity," and "meaning" should even be public issues. Agreeing with Habermas, he reminds us that the state is not a religion and therefore does not have to give meaning and identity to the citizenry by means of nationalism or patriotism (Cohen 1996).

There is a risk that the flying of different flags in Belfast is only being understood as spontaneous manifestations of sentiment by individuals who believe their identity is under threat or who are in a state of anomie. Hence, the fears that the flags are perceived to embody are being interpreted as psychological, biological, or cultural in origin - not political (Robin 2000). But the flying of these flags is not indicative of the identity crises of free-floating individuals or of specific groups or so-called communities; rather, it points to serious concerns about power and control in the new political dispensation. The real problem is uncertainty regarding Northern Ireland's future political arrangements and who will have access to power both now and later. It is profoundly linked to the way that the fears of certain sections of society (which is continuously spoken about as if it is a homogeneous whole) are stoked as a way of manipulating political outcomes.

When thinking of fear in a political context, contemporary intellectuals tend to focus more on the problems of anomie and alienation from civic spaces than they do on the way that state officials, political elites, and economic and cultural leaders instill fear (Robin 2000.) and what exactly it means. Corey Robin (2000) argues that local institutions and associations (civil society) are widely seen as the way to 
stave off the anxiety of isolation and fear, which may explain the Northern Ireland focus on the debate over single-identity and cross-community work.

Yet, although Robin (2000) contends that it is the structures of civil society that can assist us to develop secure identities and to "act confidently and without fear, exercising a more robust and purposive form of agency," he also reminds us that this alone will not rectify or address problems of power and institutional authority-anomic anxiety becomes the substitute for political fear. This is one of the risks of single-identity work in Northern Ireland.

Building civil society structures is integral to participative democracy, but by obsessively debating how civil structures can serve as sites of personal security or places where identities can be "housed" and nurtured (e.g., through building a single-identity group), we can miss the meaning and essence of the political fear at work and the political problems underlying the situation.

\section{RISK TAKING IN THE NORTH AND SOUTH}

When we consider the South African TRC process, goals such as "national unity" and "reconciliation" might easily be interpreted as liberal attempts to avoid the real underlying political fears of white South Africans alarmed at the prospect of majority rule and of black South Africans anxious about continued economic exploitation. Space does not permit a discussion on the merits of the "nationbuilding" exercise in South Africa; however, I have argued elsewhere (Hamber 2002) that, from the start, the TRC process was saturated with flawed assumptions and multiple meanings.

Implicit in the notion of national unity are the suppositions that its pursuit is a unitary and coherent process and that individual and national processes of dealing with the past are largely concurrent and equivalent (Hamber and Wilson 2002). The entire discourse of nation building was imbued with the pseudo-psychological construction of national healing, which incorrectly suggested that nations have collective psyches. The problematic results were that individual needs, such as long-term healing and the desire for justice, were subordinated, to a degree, to the collective drive to "reconcile" (Hamber and Wilson 2002).

However, despite the criticism I raise above, what is remarkable in the South African context is how many people actually embraced the nation-building discourse and the concept of reconciliation, at least at the level of hegemonic political rhetoric. ${ }^{6}$ In Northern Ireland, despite the relative successes of the peace process and the efforts of many people to build peace, not to mention the rather stable socioeconomic situation, the opposite seems to be true. Reconciliation is seldom discussed. In fact, it is a word seldom heard. There are many reasons for this. For example, reconciliation is often understood as being about assimilation and therefore entails an unwelcome request that citizens consent to the political marginalization of difference (Porter 2003) ${ }^{7}$ - and it is the issue of difference that perpetuates politics in Northern Ireland because voting still follows sectarian lines almost exclusively. 
It is interesting to compare the different reception accorded to reconciliation in South Africa and Northern Ireland. One might have predicted, given the dire state of South Africa's economy and society, including its blatant subjugation of blacks, that any broad embrace of a concept like reconciliation (for better or for worse) would have remained a distant possibility in the days immediately after the first democratic election in 1994. In Northern Ireland (not to minimize the huge impact of the conflict on the relatively small population), ${ }^{8}$ given the relative stability and prosperity of society and the narrowing gap in wealth between ethnic groups, one might have expected that reconciliation would be an attractive option, if only for economic reasons.

This is not to say there was no fear in South Africa at the time of political transition. On the contrary, it is important to remember that before the 1994 election, many whites hoarded food and sent money out of the country in expectation of a final retaliatory bloodbath consistent with their centuries-old fears of the swart gevaar (black danger) and the oppression they had meted out. However, the genuine threat (and experience, to a degree) of complete social breakdown in South Africa ultimately facilitated the acceptance (by many) of a future of uncertainty and risk, at least in the immediate post-1994 period. In contrast, it might be argued that the higher levels of social and economic stability in Northern Ireland, as well as smaller community networks and tighter local political control, has meant that there is less political risk taking.

\section{UNCERTAINTY AND RESISTANCE TO CHANGE}

Sociological, economic, and political science research on the theory of conservatism has routinely asserted that people adopt conservative ideologies out of self-interest (Jost et al. 2003). However, although self-interest is a motive capable of influencing attitudes and behavior, a recent review of the literature suggests that increased conservatism may instead be associated with the desire to overcome fear, threat, and uncertainty (Jost et al. 2003). Hence, although the economically advantaged may indeed gravitate toward conservatism out of self-interest, the disadvantaged may embrace right-wing ideologies in an effort to reduce anxiety, dissonance, and instability (Jost et al. 2003).

There is no necessary link between conservatism and a lack of enthusiasm for reconciliation, yet one might reasonably assume some correlation if reconciliation were equated, for example, with a genuine desire to tolerate difference and celebrate diversity. ${ }^{9}$ Given this, the first basic conclusion that we may draw in the South African context is that the political elites there had more to gain by suing for compromise and adopting a reconciliatory tone than is currently the case in Northern Ireland. ${ }^{10}$ That is to say, there was a close correlation between the real possibility of political, economic, and social annihilation and the real threat of more conflict in South Africa. Peace under the banner of reconciliation made inspired sense of logical self-interest. 
This meant that political leaders, especially when addressing the majority of the disadvantaged, really had to talk up the certainty of the future typified by the "rainbow nation" discourse in South Africa. This allowed many in the white minority, for instance, to overcome any conservative desires to resist the changes that had given rise to uncertainty and fear and the threat posed by the future. The risk of an uncertain future was embraced (at least to some extent).

In Northern Ireland, one might argue that self-interest is assumed (on the part of the political elite) to lie with maintaining the current system. Political power in Northern Ireland is predicated along fairly evenly balanced sectarian voting lines and resolution of the conflict may mean, for political groups, assimilation into "normal" politics in either the Republic of Ireland or the United Kingdom as minority political parties.

For nationalists, however, the situation is not as clear-cut. Political elites might have some self-interest in maintaining sectarian politics, but at the same time their entire ideology is based on embracing the "uncertainty" of a united Ireland. Perhaps this is one reason why their whole approach to the peace process seems more positive at this stage. The other alternative is that the "nationalist" ideal of a united Ireland trumps the desire for political power in the short term. ${ }^{11}$

For Unionists, however, the result is that politicians continually have to talk down the peace process and shun concepts such as reconciliation to maintain some of their power. Unlike the whites in South Africa, the Protestants of Northern Ireland are constantly fed, by the politicians who represent them, a diet of political rhetoric rich in uncertainty, fear, and the potential threat posed by the future. The personal uncertainty that some individuals may rightly believe about the future (given that the situation is far from settled and constitutional changes will have social, cultural, and political implications) is subsumed by the Unionist political project to protect the status quo. The totalizing discourses of fear and threat take personal concerns about social, economic, and political issues and draw them into the frame of ethnic politics. Individuals are not merely anxious about what the future holds for them personally, they are also being told to worry, first and foremost, about what the future holds for each of them as a Protestant. This linking of the emotive language of fear to identity politics makes in- and out-group ethnic boundaries even more rigid.

Emotional discourse (fear in this case) is thus implicated in the play of power and provides a locus of resistance to change (Lutz, cited in Svasek 2002). Consequently, it shapes social life and provides the moral framework in which power relations are played out and discussed (Svasek 2002). And now the Israeli flag fluttering in a loyalist estate starts to make sense. To those living there, it is largely a conservative symbol representing a reaction to uncertainty, threat, and fear exacerbated by political rhetoric. It is a symbol of resistance to change. The result is that some hard-line loyalists retreat to embrace a simple message. ${ }^{12}$ What they need to counteract the political fear that they believe is "a government here like the Israelis. They don't mess, and they don't care about world opinion" (Addley 2002: 2). ${ }^{13}$ 


\section{CONCLUSION}

This article is an analysis aimed at beginning a process of exploration and theorizing about the relevance of the concept of fear in the transitional justice literature and in debates about resolving political conflicts. It is meant to serve as a springboard to further debate. That being said, it is important, in conclusion, to reiterate that fear in this article is dealt with through the prism of the political. The article argues that fear in societies coming out of violence can be as much, if not more, a product of political and social context and discourse as it is a real and objective entity that exists in and of itself. We need to pay attention to political fear in transition and peace processes and to treat it as a problem that is primarily political and not merely psychological or cultural. This is important because it is only by dealing with fear in this way during times of political transition that we can seek solutions to its manifestation. These lie in a political context that strives for social justice and democracy in a contested environment and not in the quest for individual healing, secure identities, self-understanding, or anxiety reduction as ends in and of themselves.

\section{NOTES}

1. Space does not permit a thorough discussion of the concept of transition and its multiple meanings. For the purposes of this article, transition is defined as something more than mere "regime change," something less than transformation and certainly not merely a shift from authoritarian to democratic rule (interview with Jackie Cock, Department of Sociology, University of the Witwatersrand, Johannesburg, 15 June 2000; cited in Brocklehurst et al. 2001). As Friedman states, “... if there is a reasonable expectation among a significant section of society that the basic rules governing society could change, then that society is still in a period of transition." He argues that "transition" involves a change from one set of rules to something else and that policy, therefore, is made in conditions of uncertainty (cited in Brocklehurst et al. 2001).

2. This is no place for a comprehensive discussion about the concept and usage of PTSD. However, it is interesting to note that many victim groups with which I have spoken in Northern Ireland and in other countries share this view. On several occasions, people who are "seen as victims" have come to me perplexed and asked me what this "posttraumatic stress thing" is that they have heard about. Generally speaking, it has never been their main personal concern or their way of understanding what has happened to them. I certainly do not intend to trivialize people's suffering, but concepts such as PTSD often change the local language or communal way of talking about suffering-further disempowering so-called victims as now they have an "illness" and the solution lies somewhere in a clinic or a therapy room, rather than in the hands of society or even themselves.

3. What I mean by this point is that the genuine impact (at a psychological and cultural level) of political violence is seldom grasped by policymakers and politicians. It is easier to think about extreme political violence as having a beginning, middle, and end (and the development of mechanisms that deal with it, like testimony and counseling, as direct and outcome-driven interventions) than to consider its profound impact. To understand completely the impact of large-scale political violence and to find ways of preventing it in the future, the analysis needs to be grounded in the inner psychic processes of individuals as well as in the social and cultural contexts of large-scale violence and trauma (Robben and Suarez-Orozco 2000).

4. The purpose of this article is not to debate whether these views are correct but rather to try and understand their consequences.

5. The CRC was set up in 1990 as an independent charity to promote better community relations between Protestants and Catholics in Northern Ireland and, equally, to promote the recognition of cultural diversity. It is one of the major funders and channels for government and European Union funds supporting the peace process in Northern Ireland (see http://www.community-relations.org.uk).

6. This point is not meant to imply that everyone in South Africa supported the "reconciliation" approach; rather, it represents an analysis of the overall and dominant perspective. Different groups had very divergent 
understandings of reconciliation. There were some groups, like the far right wing and, to a certain degree, the Inkatha Freedom Party, which never fully championed the reconciliation agenda.

7. Porter also highlights a range of other reasons, including, for example, the fact that reconciliation and forgiveness are often equated, creating a range of confusions theoretically and politically for different groups on the basis of the benign marriage between religion and politics implicit in such a view.

8. Out of a population of about 1.5 million people, over thirty-six hundred have been killed in the last 30 -odd years in Northern Ireland and at least 10 times as many have been injured. These figures are typical of a "low intensity conflict," defined as having an overall death rate of 2.25 per 1,000 population. The death rate in Northern Ireland is higher than in Argentina ( 0.32 per 1,000), about the same as South Africa, but substantially lower than El Salvador (20.25 per 1,000) or Cambodia (237.02 per 1,000). (figures from Morissey and Smyth 2002).

9. This is assuming a somewhat genuine grasp of the concept as implying tolerance for difference and the celebration of cultural diversity. Of course, there is an argument that the popularization of the concept of reconciliation globally is another way that power relations can be asserted under a benign guise (Porter 2003).

10. Elsewhere, I have examined the complexities of the debate about whether the South African TRC, for example, was a radical process trying to address the past or whether, from a more cynical perspective, the notion of "reconciliation" is a complex modern foil used to market unfavorable compromises made during political negotiations (Hamber 2002, 2003).

11. Nationalist parties in the north would have fairly limited, albeit growing, power on the island as a whole if it were to be united at this stage.

12. The word some is used deliberately as this article is a general analysis. It does not presume all people in certain communities or areas would share the views hypothesized about here. In fact, research still needs to be done on how many people actually support the flying of different flags. The impression is that this is actually a very small proportion of the local community. This points to yet another level of fear, that is, the fear of people in certain communities to challenge those responsible for flying certain flags. This question is beyond the scope of the present article.

13. This opinion is not one that has been mentioned publicly by any politician to my knowledge. The quote comes from a newspaper piece in which the journalist interviews a shopkeeper selling Israeli flags for $£ 7$ each in a fairly loyalist area of Belfast.

\section{REFERENCES}

AdDley, E. (2002) Riot city. Guardian (London), 11 June, 2.

Anstey, M. (1998) Case study: South Africa. In P. Harris and B. Reilly (eds.) Democracy and Deep-Rooted Conflict: Options for Negotiations (Stockholm: International IDEA).

Boraine, A. (2000) A Country Unmasked: South Africa's Truth and Reconciliation Commission (New York: Oxford University Press).

Brocklehurst, H., Stott, N., Hamber, B. and Robinson. G. (2001) Lesson drawing: Northern Ireland and South Africa. Indicator South Africa, 18, 89-95.

Buruma, I. (1999) The joys and perils of victimhood. New York Review of Books, 8 April, 4-9.

Camerer, L., Louw, A., Shaw, M. Artz, L. And Scharf, W. (1998) Crime in Cape Town: Results of a City Victim Survey (Pretoria: Institute for Security Studies).

CAP Gemini ERnst And Young (2001) Summary of the Evaluation of the Memorial Fund (Belfast: Cap Gemini Ernst and Young).

Cohen, S. (1996) Crime and politics: spot the difference. British Journal of Sociology 47, 1-21.

Community Relations Council (2003) A Shared Future: A Consultation Paper on Improving Relations in Northern Ireland. Response by the Community Relations Council (Belfast: Community Relations Council).

Deloitte And Touche (2001) Evaluation of Services to Victims and Survivors of the Troubles: Summary Report (Belfast: Deloitte and Touche).

Dywer HogG, C. (2002) Raising the standards: Israeli flags are hoisted in one part of the city while, in another, Palestinian colours fly. But this isn't the West Bank. Independent (London), 18 June, 6.

Feldman, A. (1991) Formations of Violence: The Narrative of the Body and Political Terror in Northern Ireland (Chicago: University of Chicago Press).

HAMBER, B. (1998) The burdens of truth: an evaluation of the psychological support services and initiatives undertaken by the South African Truth and Reconciliation Commission. American Imago 55, 9-28. 
Hamber, B. (2000) Have no doubt it is fear in the land: an exploration of the continuing cycles of violence in South Africa. South African Journal of Child and Adolescent Mental Health 12, 5-18.

Hamber, B. (2001) Does the truth heal? A psychological perspective on the political strategies for dealing with the legacy of political violence. In N. Biggar (Ed.) Burying the Past: Making Peace and Doing Justice After Civil Conflict (Washington, DC: Georgetown University Press).

HAMBER, B. (2002) "Ere their story die": truth, justice and reconciliation in South Africa. Race and Class 44, $61-79$.

HAmber, B. (2003) Rights and reasons: challenges for truth recovery in South Africa and Northern Ireland. Fordham International Law Journal 26, 1074-1094.

HAMBER, B. AND WiLSON, R. (2002) Symbolic closure through memory, reparation and revenge in post-conflict societies. Journal of Human Rights 1, 35-53.

Humphrey, M. (2002) The Politics of Atrocity and Reconciliation: From Terror to trauma (London: Routledge).

IgnatiefF, M. (1997) Getting away with murder. Special Correspondent Programme, BBC2, London.

Jost, J. T. Glaser, J. Kruglanski, A. W. And Sulloway, F. J. (2003) Political conservatism as motivated social cognition. Psychological Bulletin 129, 339-375.

KING, M. (2002) An interview with Noam Chomsky: it's extremely easy to frighten people. Austin Chronicle, 18 October; available online at http://www.austinchronicle.com/issues/dispatch/2002-10-18/pols_feature3.html.

Morissey, M. And Smyth, M. (2002) Northern Ireland After the Good Friday Agreement: Victims, Grievance and Blame (London: Pluto Press).

Novick, P. (2001) The Holocaust and Collective Memory (London: Bloomsbury).

O'Clery, C. AND Moriarity, G. (2003) Post-war Iraq will top agenda at Hillsborough summit talks. Irish Times (Dublin), 8 April, 1.

O’toole, F. (2003) Meaning in a historical footnote. Irish Times (Dublin), 8 April, 18.

PORTER, N. (2003) The Elusive Quest: Reconciliation in Northern Ireland (Belfast: Blackstaff Press).

Robben, A. C. G. And Suarez-Orozco, M. M. (2000) Cultures Under Siege: Collective Violence and Trauma (Cambridge, UK: Cambridge University Press).

Robin, C. (2000) Fear: a genealogy of morals. Social Research 67, 1085-1116.

SAUL, J. S. (2002) Cry the beloved country: the post-apartheid denouement. In Jacobs, J. and Calland, R. (eds.) Thabo Mbeki's World: The Politics and Ideology of the South African President (Pietermaritzburg: University of Natal Press).

Shirlow, P., Murtagh, B., Mesev, V., And McMullan, A. (2002) Measuring and Visualizing Labour Market \& Community Segregation: A Pilot Study (Belfast: Office of the First Minister and Deputy First Minister).

Shrlar, J. (1989) The liberalism of fear. In Rosenblum, N. (ed.) Liberalism and the Moral Life (Cambridge: Harvard University Press).

Sparks, A. (1997) Tomorrow Is Another Country: The Inside Story of South Africa's Negotiated Revolution (London: Arrow Books).

SuMmerfiELD, D. (2001) The invention of post-traumatic stress disorder and the social usefulness of a psychiatric category. British Medical Journal 322, 95-98.

SvAŠEK, M. (2002) The politics of emotion: emotional discourses and displays in post-Cold War contexts. FocaalEuropean Journal of Anthropology 39, 9-27.

Tudor, A. (2003) A (macro) sociology of fear? Sociological Review 51(2), 238-256.

Tutu, D. (1999) No Future Without Forgiveness (London: Rider).

Young, C. (2003) Explaining the conflict potential of ethnicity. In Darby, J. and MacGinty, R. (eds.) Contemporary Peacemaking: Conflict, Violence and Peace Processes (Houndsmill, Basingstoke: Palgrave MacMillan). 